\title{
Method to obtain abundance indices in the population of Farfantepenaeus californiensis (Holmes, 1900) from the Gulf of Tehuantepec, Oaxaca, Mexico
}

\author{
Método para obtener índices de abundancia en la población de Farfantepenaeus californiensis \\ (Holmes, 1900) del Golfo de Tehuantepec, Oaxaca, México \\ Pedro Cervantes-Hernández ${ }^{1^{*}}$ \\ ${ }^{1}$ Instituto de Recursos, Universidad del Mar - Puerto Ángel. A. P. 47., C. P. 70902, Puerto Ángel, Oaxaca, México. *Alumno \\ adscrito al posgrado del Instituto de Ciencias del Mar y Limnología, UNAM, México \\ pch@angel.umar.mx
}

\begin{abstract}
Resumen.- Se propone un método para modelar la variación anual de la abundancia de Farfantepenaeus californiensis (Holmes, 1900) del Golfo de Tehuantepec, Oaxaca, México. El análisis de componentes principales (ACP) se utilizó para obtener dos índices poblacionales: la abundancia de reclutas o índice FR y la abundancia de reproductores o índice DR. El grupo de cuatro meses de edad se utilizó para calcular el índice FR y los grupos de seis a 11 meses, para calcular el índice DR. El análisis de la tasa de mortalidad por pesca (F) indicó que los camarones entre $12(\mathrm{~F}=0,88$ mensual) y 16 meses $(\mathrm{F}=$ 1,66 mensual) fueron sobre-explotados, y que los camarones de tres meses de edad se observaron parcialmente reclutados a la pesquería ( $\mathrm{F}=0,02$ mensual); por esta razón, el ACP no generó cargas factoriales significativas en ninguno de los índices. Los grupos de edad seleccionados por el ACP en cada índice estimado, se observaron sub-explotados en la población natural, de modo que, estos grupos de edad fueron considerados importantes para mantener la continuidad de la pesquería entre 1989 y 1998. Con base en la variación anual de la abundancia FR y DR obtenida por el análisis de población virtual (APV), se observó que de julio a agosto/septiembre, la abundancia de los reclutas fue mayor que la de los reproductores, mientras que de octubre a enero, la abundancia de los reproductores fue mayor que la de los reclutas.
\end{abstract}

Palabras clave: Camarón café, reclutas, reproductores, variación anual, Pacífico mexicano

\begin{abstract}
A method to model the annual abundance variation of the Farfantepenaeus californiensis (Holmes, 1900) from the Gulf of Tehuantepec, Oaxaca, Mexico is proposed. Principal components analysis (PCA) was used to obtain two population indices: the abundance of recruits, or FR index, and the abundance of spawners, or DR index. The age group of four months was used to calculate the FR index and the age groups from six to 11 months were used to calculate the DR index. The analysis of the fishery mortality rate $(\mathrm{F})$ indicated that shrimp between 12 ( $F=0.88$ monthly) and 16 months ( $F$ $=1.66$ monthly) were overfished, and that 3 months old shrimp were observed partially recruited to the fishery $(F=0.02$ monthly); for this reason, PCA did not show a significant factor loading in any of the indices. The age groups selected by PCA in each calculated population index were observed underfished in the natural population so that these age groups were considered very important to maintain the continuity of the fishery between 1989 and 1998. Based on the annual abundance variation of FR and DR obtained by the virtual population analysis (VPA), from July to August/September, the abundance of recruits was higher than the spawners, while from October to January, the abundance of spawners was higher than the recruits.
\end{abstract}

Key words: Brown shrimp, recruits, spawners, annual variation, Mexican Pacific

Chiapas, Chiapas ( $14^{\circ} 41^{\prime} \mathrm{N}$ and $\left.92^{\circ} 24^{\prime} \mathrm{W}\right)$. The fishing zone 90 is composed of five sub-sectors, with an approximate distance of $143 \mathrm{~km}$ between these sub-zones and a total area of 5,988 $\mathrm{km}^{2}$ of continental platform (Sepúlveda \& Soto 1991). A great number of salt marshes and coastal lagoons are located along the coastline, of which the most important are 'El Sistema Lagunar Huave' in Oaxaca and 'La Laguna del Mar Muerto', shared by the states of Oaxaca and Chiapas (Reyna-Cabrera \& Ramos-Cruz 1998) (Fig. 1). 


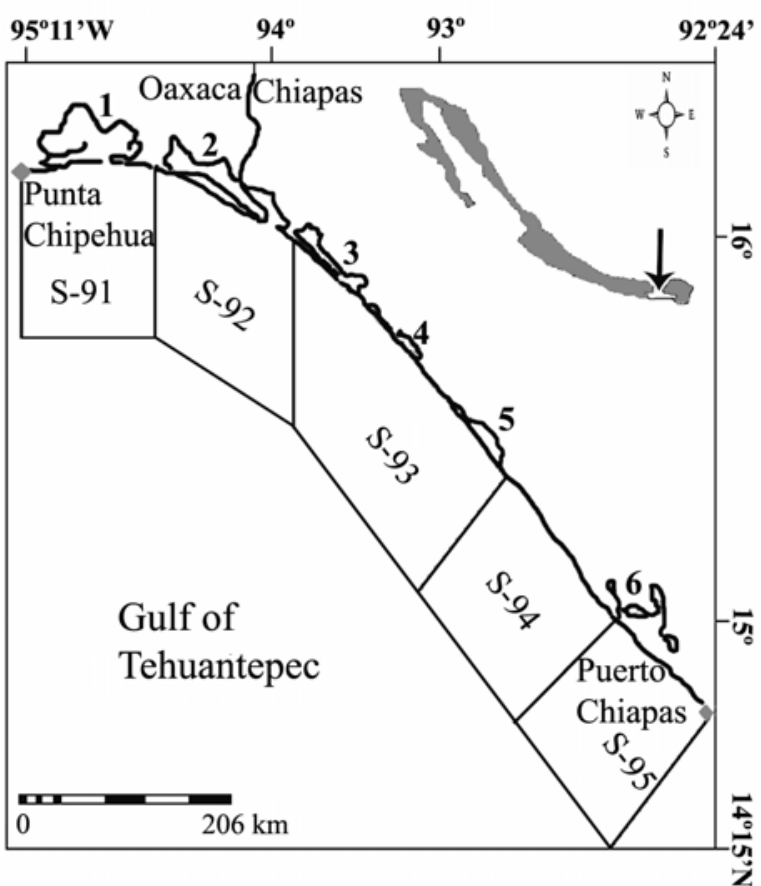

Figure 1

Geographic location of fishing zone 90 in the Gulf of Tehuantepec. S-91 to S-95 are sub-sectors. (1) Sistema Lagunar Huave, (2) Laguna Mar Muerto, (3) La Joya Buenavista, (4) Los Patos-Solo Dios, (5) Carretas-Pereyra and (6) Chantuto-Panzacola

Localización geográfica de la zona de pesca 90 en el Golfo de Tehuantepec. S-91 to S-95 son sub-sectores. (1) Sistema Lagunar Huave, (2) Laguna Mar Muerto, (3) La Joya Buenavista, (4) Los Patos-Solo Dios, (5) Carretas-Pereyra y

(6) Chantuto-Panzacola

The marine shrimp fishery is regulated through a closure system from three to four months per year (from May/June to August). Ships operate from five to 40 fathoms (i.e., 9.1 to $72.8 \mathrm{~m}$ ), using trawl nets with light mesh of 57.15 mm (Instituto Nacional de la Pesca 2004). The total capture is dominated by brown shrimp (57\%), while white and blue shrimp represent $37 \%$ and $6 \%$, respectively (Instituto Nacional de la Pesca 2005).

To model the annual variation of the abundance of brown shrimp in the Gulf of Tehuantepec, a new method was proposed. The correlation obtained between the abundance values by age groups of brown shrimp and a multivariate classification technique were used to obtain a new classification of these age groups within two population indices: the abundance of recruits or FR index, and the abundance of spawners or DR index. The fishing mortality rate $(\mathrm{F})$ for each age group was estimated to identify the overfished age groups, as well as those that were underfished or with a recommendable abundance level in the natural population. The underfished age groups were considered very important to maintain the fishery continuity. This work does not include a detailed discussion of the effect of the environmental variability on annual abundance variation of the population indices, because this is included in other work developed by the authors $^{1}$. The methodological process for obtaining the annual abundance variation FR and DR is the main objective of this article.

\section{Material and methods}

Monthly commercial catch data of the brown shrimp classified by categories (10-14, 15-20, 21-25, 26-30, 31$35,36-40,41-50,51-60$ and 60 abdomens by pound) were used. This information was obtained in the fishing zone 90 from the Gulf of Tehuantepec, from 1989 to 1998, and it was provided to the Universidad del Mar in Puerto Angel, Oaxaca, Mexico, by the Centro Regional de Investigación Pesquera (CRIP) of Salina Cruz, Oaxaca, Project CRIP-UMAR: 2IR043.

The categories and the technique proposed by Gracia (1991) were used to obtain the total number of brown shrimp cohorts and the monthly abundance or number of shrimp captured by age groups. The technique was adapted for F. californiensis, considering combined sexes, because data for separate sexes were not available in the comercial catch. The process to follow is:

1. I assumed that the registries of the abdomens weight within each category are distributed normally $\mathrm{Z}(0,1)$. The probability of the weight of each abdomen $\mathrm{P}(\mathrm{a})$ was estimated using the average and the standard deviation that resulted in each category.

2. The division of the total weight of a category between its corresponding sum of $\mathrm{P}(\mathrm{a})$ generates a conversion factor. The factor was multiplied by $\mathrm{P}(\mathrm{a})$ and divided by the frequency of each abdomen to obtain the estimate of the total number of shrimp by unit of abdominal weight. This process was applied every month during the period of study.

3. The parameters of $F$. californiensis reported by Chávez (1979) $\left(L_{\infty}=242 \mathrm{~mm}, \mathrm{t}_{\mathrm{o}}=-0.344, \mathrm{k}=0.186\right.$ and $W_{\infty}=220$ g) were used to estimate the age of shrimp by unit of abdominal weight.

${ }^{1}$ Cervantes-Hernández P, B Sánchez-Meraz, J Serrano-Guzmán, A Frías-Velazco, S Ramos-Cruz \& A Gracia-Gasca (en rev) Variación anual de la abundancia de reclutas y reproductores de Farfantepenaeus californiensis (Holmes, 1900) en el Golfo de Tehuantepec. Hidrobiologica. 
The previous process generated a capture matrix whose dimensions were: 120 rows (r), or total number of age-cohorts, and 14 columns (q), or total number of age groups (between three and 16 months of age). A cohort, or a year-class, is a group of organisms that were spawned in the same year (Quinn \& Deriso 1999). An age group is a group of organisms of the same age, but of different cohorts (Sparre \& Venema 1995).

The natural mortality rate $(\mathrm{M})$ reported by RamosCruz et al. (2006) in the marine phase of the brown shrimp from the Gulf of Tehuantepec between 1989 and 1998, was used to calculated the virtual population analysis (VPA). M was estimated at 0.22 monthly, i.e., from 100 shrimps, 22 died monthly of natural causes.

Based on the VPA and the age-cohort analysis of Pope (1972), the capture matrix was used to model the annual abundance variation of recruits and spawners in each cohort for each age group in the past months and years.

The interaction of the F. californiensis population with other natural populations in the Gulf of Tehuantepec was not considered; nevertheless, the natural mortality rate estimated by Ramos-Cruz et al. (2006) was used to cover deaths by predation, disease and death due to old age (density dependent mortality) and deaths caused by environmental variability (density independent mortality). In this work, the natural mortality rate was assumed to be constant during the fishable life of all age-cohorts.

The VPA generated an abundance matrix $\left(\mathrm{X}_{\mathrm{VPA}}\right)$ with the same dimensions of the capture matrix. The VPA calculates past stock abundances (abundance matrix) based on past catches (capture matrix). The $\mathrm{X}_{\mathrm{VPA}}$ matrix was standardized based on the normal probability distribution using the number of columns or age groups. The function for this purpose is:

$$
Z_{x r q}=\frac{\left(G_{x r q}-G_{q}\right)}{\sigma_{q}}
$$

where:

$r$ is the age-cohort

$q$ is the age group

$Z_{x r q}$ is the standard value of the abundance in month $\mathrm{x}$ of the cohort $r$ at the age $q$

$G_{x r q}$ is the value of the virtual abundance in month $x$ of the cohort $r$ at the age $q$

$G_{q}$ is the average of the virtual abundance of the age group $q$

$\sigma_{q}$ is the standard deviation of the virtual abundance of the age group $q$
When applying function 1 on $\mathrm{X}_{\mathrm{VPA}}$ matrix, the standardized matrix $\left(\mathrm{Z}_{\mathrm{VPA}}\right)$ was obtained with the same dimensions as $\mathrm{X}_{\mathrm{VPA}}$. The $\mathrm{Z}_{\mathrm{VPA}}$ matrix and the functions proposed by Pielou (1984) were used to obtain the correlation matrix between the age groups previously mentioned. The functions are:

$$
\begin{array}{r}
C S P C=Z_{V P A} * Z_{V P A}^{\prime} \\
m_{-} \text {corr. }=\frac{C S P C}{r}
\end{array}
$$

where:

CSPC is the sum of squares of the cross products matrix $Z_{\text {AVP }}$ is the transpose of $Z_{A V P}$ matrix

m_corr. is the correlation matrix

$r$ is the total number of age-cohorts or rows of the $\mathrm{Z}_{\mathrm{VPA}}$ matrix

Following the procedure described by Hair et al. (1999), a principal components analysis (PCA) was applied to the correlation matrix obtained with function (3). Considering the correlation obtained between the abundance values by age groups of brown shrimp, the PCA was used to obtain a new classification of these groups within two population indices: the abundance of recruits, or FR index, and the abundance of spawners, or DR index. Based on the theoretical arguments of the PCA described by Hair et al. (1999), the significant factor loading values greater than or equal to 0.7 was used to identify the most important age groups within each population index. Factor loading is the correlation between the principal component and the variables (Hair et al. 1999). The factor loading represents the most important information on which the interpretation of PCA is based (Uriel 1995).

Once significant age groups were chosen within each population index, two linear functions were obtained by the PCA in order to model the annual abundance variation of the population indices. The functions are:

$$
\begin{aligned}
& F R=\lambda_{i} * G_{x r q} \\
& D R=\lambda_{i} * G_{x r q}
\end{aligned}
$$

where:

$F R$ is the abundance of recruits of $F$. californiensis

$D R$ is the abundance of spawners of $F$. californiensis

$\lambda_{i}$ is the linear coefficient or eigen-vector estimated for each age group $\left(G_{x r q}\right)$ with significant factor loading in each population index (i). $G_{x r q}$ is the value of the virtual abundance in the month $x$ of the cohort $r$ at the age $q$ 


\section{Table 1}

General procedure to obtain the annual abundance variation of recruits and spawners of $F$. californiensis in the Gulf of Tehuantepec

Proceso general para obtener la variación anual de la abundancia de reclutas y reproductores de F. californiensis en el Golfo de Tehuantepec

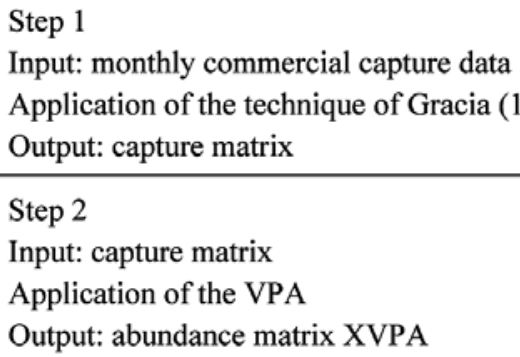

Step 2

Input: capture matrix

Application of the VPA

Output: abundance matrix XVPA

Step 3

Input: abundance matrix $\mathrm{X}_{\mathrm{VPA}}$

Application of the normal probability distribution

Output: standardized matrix $Z_{\mathrm{VPA}}$

Step 4

Input: standardized matrix $\mathrm{Z}_{\mathrm{VPA}}$

Application of the Pielou's model (1984)

Output: correlation matrix

Step 5

Input: correlation matrix

Application of the PCA

Output: population indices (FR and DR)
To validate the presence of all age groups selected within each population index, I considered the biological characteristics of Penaeus life cycle, described by Gracia et al. (1997), and the annual variation of the massive egglaying of mature brown shrimp females in phase IV, reported by the Instituto Nacional de la Pesca (2004) for the Gulf of Tehuantepec between 1982 and 2002.

Table 1 shows the general procedure to obtain the annual abundance variation of FR and DR.

The VPA was used in order to obtain the fishing mortality rate (F) for each age group. $F$ values were used to identify the overfished age groups, as well as those that were underfished in the natural population.

\section{Results}

Two principal components were extracted by the PCA: Cp1 with an eigen-value of 6.79 and Cp2 with an eigenvalue of 1.95. The variance obtained for both components was $62.49 \%$. Cp1 presented significant factor loading in the age groups of $6,7,8,9,10$ and 11 months, while in Cp2, significant factor loading was obtained in the age group of four months (Table 2).

The fishery mortality rate (F) presented a sustained increase from four $\left(\mathrm{F}_{4}=0.18\right.$ monthly $)$ to $16\left(\mathrm{~F}_{16}=1.66\right.$ monthly) months of age. I observed a low fishery mortality rate $(\mathrm{F})$ in the age group of three months $\left(\mathrm{F}_{3}=\right.$ 0.02 monthly) (Fig. 2). This estimation suggests that this age group was partially recruited to the fishery, and for this reason, the PCA did not show significant factor loading in any of the extracted components (Table 2).

Table 2

Values of factor loading obtained by PCA for each age group in Cp1 (DR index) and Cp2 (FR index). The values of factor loading greater than or equal to 0.7 are significant $(P<0.05)$

Valor de carga factorial obtenidos por el ACP para cada grupo de edad en Cp1 (índice DR) y Cp2 (índice FR). Los valores de carga factorial mayores o iguales a 0,70 son significativos $(P<0,05)$

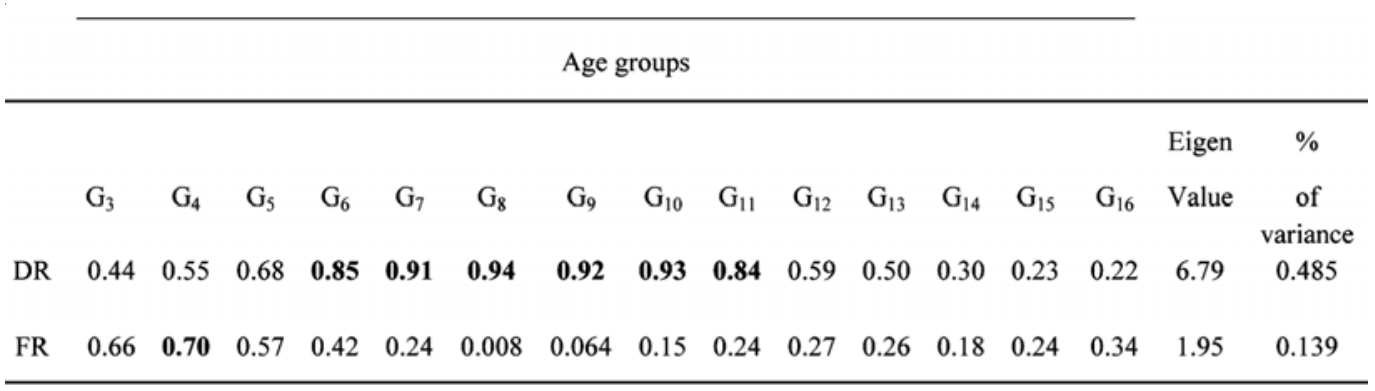

FR is the abundance of recruits of F. californiensis, DR is the abundance of spawners. Letter G sub index $q$ is equal to $\mathrm{G}_{\mathrm{xrq}}$ included in functions 1 and 4 
In the principal component $\mathrm{Cp} 1$, the age groups of 12, 13, 14, 15 and 16 months did not show significant factor loading (Table 2, Fig. 2). The age groups from 12 to 16 months are shrimp with a high reproductive potential in the natural population (Chávez 1979, Sierra 1993, Reyna-Cabrera \& Ramos-Cruz 1998, Instituto Nacional de la Pesca 2004). Nevertheless, I observed that their abundance within the natural population was reduced and their contribution to the reproductive potential of this species seemed to mask the high levels of the fishery mortality rate to which they were subjected (between 0.88 and 1.66 monthly) (Fig. 2). For this reason, I considered that the age groups from 12 to 16 months were overfished in the Gulf of Tehuantepec from 1989 to 1998.

In the principal component $\mathrm{Cp} 1$, the fishery mortality rate estimated for age groups from six to 11 months was lower in comparison with the groups from 12 to 16 months of age in the same component (between 0.42 and 0.81 monthly) (Fig. 2). For this reason, the age groups from six to 11 months were considered underfished in the Gulf

of Tehuantepec between 1989 and 1998.

Underfished $F$. californiensis age groups in natural population were used with a significant factor loading in the components $\mathrm{Cp} 1$ and $\mathrm{Cp} 2$ in order to obtain the FR and DR indices (Fig. 2 and Table 2). To calculate the FR index of brown shrimp the group of four months was used because this age group was underfished and it obtained a significant factor loading in the component Cp2. To obtain the DR index of brown shrimp the groups from six to 11 months were used because these age groups were underfished and they obtained a significant factor loading in the component $\mathrm{Cp} 1$. According to the $\mathrm{F}$ analysis (Fig. 2 ), the age groups that were underfished in the natural population were considered very important to maintain the continuity of $F$. californiensis fishery in the Gulf of Tehuantepec from 1989 to 1998.

The annual abundance variation of $F$. californiensis recruits and spawners was modeled using the following linear functions obtained by the PCA:

$$
\mathrm{FR}=0.4030 * \mathrm{G}_{4}
$$

$$
\mathrm{DR}=-\left(0.578 * \mathrm{G}_{6}\right)+\left(0.283 * \mathrm{G}_{7}\right)+\left(0.0108 * \mathrm{G}_{8}\right)-\left(0.0735 * \mathrm{G}_{9}\right)+\left(0.00045^{*} \mathrm{G}_{10}\right)-\left(0.0033^{*} \mathrm{G}_{11}\right)
$$

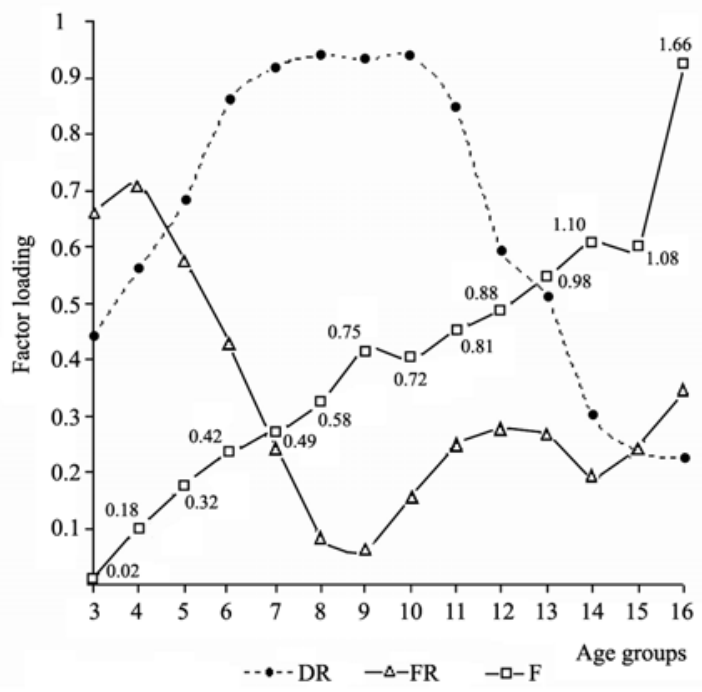

Figure 2

Monthly fishery mortality rate (F) estimated for all age groups in FR and DR The continuos line with rectangles represent $F$, the continuos line with triangles represents the factor loading of the FR index and the discontinuous line with circles represents the factor loading of the DR index

Tasa mensual de mortalidad por pesca (F) estimada para todos los grupos de edad en FR y DR La línea continua con rectángulos representa $\mathrm{F}$, la línea continua con triángulos representa las cargas factoriales del índice FR y la línea discontinua con círculos representa las cargas factorales del índice DR where:

FR is the abundance of $F$. californiensis recruits

DR is the abundance of $F$. californiensis spawners

Letter $G$ sub index number is equal to $G_{x r q}$ included in functions 1 and 4

The constants are the linear coefficient or eigen-vector $(\lambda)$ estimated for each age group $G_{x r q}$ in FR and DR.

According to (6), the abundance of brown shrimp recruits showed maximums during August 1989, 1990 and 1993, July 1991, 1994 and 1996, May 1992, April 1995 and September 1997 and minimums in January of each year (Fig. 3). According to (7), the abundance of brown shrimp spawners presented maximums during November 1989, December 1990 and 1993, October 1991, 1994 and 1996, August 1992 and January 1996 and 1997; and minimums in April and May of each year (Fig. 3). Based on these results, the abundance of recruits was higher than the spawners from July to August/ September whereas the abundance of spawners was higher than the recruits from October to January. The abundances were estimated in number of recruits and spawners $\mathrm{x} 10^{4}$. A four-months dephase was observed between the maximum abundance of FR and DR.

\section{Discussion}

Knowledge of the annual abundance variation of recruits and spawners is critical to the management of all fisheries (Penn \& Caputi 1986). For an organism whose age cannot 


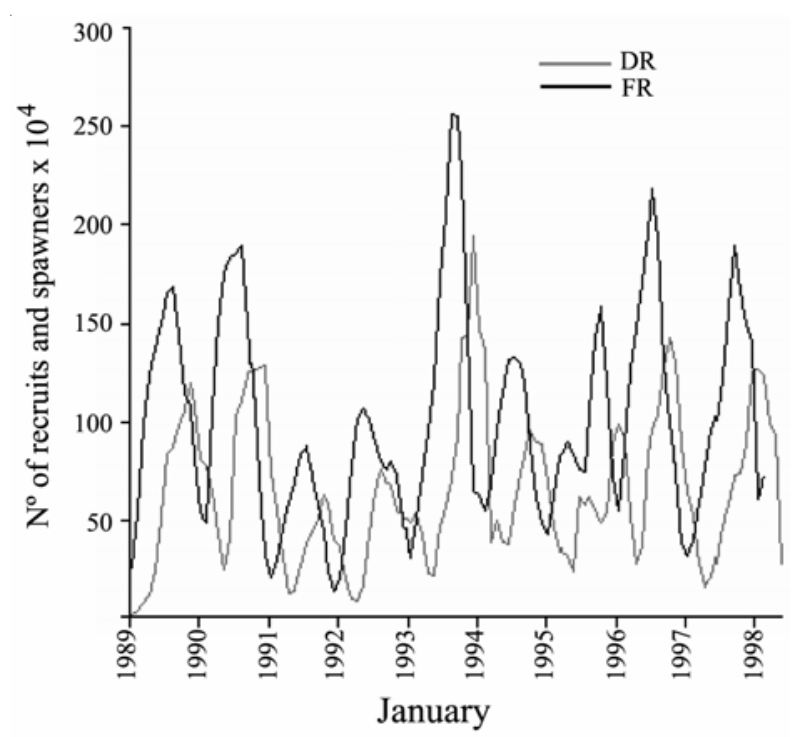

Figure 3

Annual variation of the abundance of the population indices FR and DR of $F$. californiensis between 1989 and 1998 in the Gulf of Tehuantepec. The black line is the abundance recruit's index and the gray line is the abundance of spawners' index

Variación anual de la abundancia de los índices poblacionales FR y DR de F. californiensis entre 1989 y 1998 en el Golfo de Tehuantepec. La línea negra es el índice de la abundancia de reclutas y la línea gris es el índice de la abundancia de reproductores

be accurately estimated (such as penaeid shrimp), the length-cohort and age-cohort methods can identify the recruitment and spawning patterns in natural populations (Watson et al. 1996). Nevertheless, Ye (2000) indicated that for all the shrimp fisheries, accurate commercial catch-at-age data are not available in most cases. For this reason, the abundance of recruits and spawners is modeled together most often using a relative abundance index, the catch per unit of effort (CPUE).

CPUE was not employed here because the main objectives of this work were to model separately the annual variation of the abundance of recruits and spawners of F. californiensis, as well as to understand the effects of exploitation on the age groups that were used to calculate the population indices (FR and DR).

In the Pandalus jordani stock from the coast of Oregon, U.S.A., Hannah (1999) obtained indices of recruits and spawners specifically between April-May and September-October from 1979 to 1996 (at a value of M $=1.15$ monthly). The recruits' index was obtained by adding two components: a) an estimate of the abundance of two year old shrimp, obtained of the CPUE between
April and May (year t) and b) a sum of the CPUE of the one year old shrimp during the previous year $(\mathrm{t}-1)$. The author used the same age groups to estimate the spawners' index with an average of the CPUE from September to October. The maximum abundance of recruits was observed in April, whereas, the maximum abundance of the spawners was observed from September to October.

I believe that Hannah's method (1999) is apparently an improvement over the swept area model described by Sparre \& Venema (1995). The abundance indices obtained by Hannah based on the CPUE did not consider other age groups of $P$. jordani rather only older shrimp of one and two years were considered. In the California shrimp fishery, Lo (1978) indicated that these age groups have been reported completely recruited to the fishery. For this reason, I consider that the indices obtained by Hannah do not describe the process of recruiment of the young shrimp that are beginning to be exploited in the marine environment. Nevertheless, the author obtained interesting results based on the age groups completely recruited to the fishery, due to the fact that the work of Hannah was supplemented with an analysis of the percentage of egg-laying of mature $P$. jordani females in the last months indicated. Based on this, Hannah (1999) indicated that April was a critical month for larval survival and from September to October the larval survival was greater.

The association between the maximum abundance of spawners and the massive egg-laying of mature females in the shrimp fisheries from the Gulf of Mexico was reported by Gracia et al. (1997). This author indicated that the massive egg-laying of mature females in the natural populations of shrimp generally coincide with an increase in the abundance of spawners in the marine environment.

To explain the association described by Gracia et al. (1997) in F. californiensis, the report of the Instituto Nacional de la Pesca (2004) was used, which describes the massive egg-laying seasons of mature brown shrimp females in phase IV in the Gulf of Tehuantepec from 1982 to 2002. Phase IV in the shrimp of the genus Penaeus is characterized by dark colored mature ovaries and an empty gonadal mass (Sandoval-Quintero \& Gracia 1998).

The Intituto Nacional de la Pesca (2004) reported a higher percentage of egg-laying of brown shrimp mature females in phase IV from October to January. The maximum abundance of spawners was also obtained during these dates. On the other hand, the lowest percentage of egg-laying of brown shrimp mature females in phase IV was observed from July to September. The minimum abundance of spawners was also obtained during these same dates (Fig. 3). 
Solana-Sansores et al. (1989) modeled the seasonal abundance changes of Farfantepenaeus aztecus in the northwestern Gulf of Mexico using the monthly values of the number of organisms by age groups from 1974 to 1982. The data were first analyzed with VPA and later with the PCA in order to obtain two population indices: the recruits' strength and adults' density. The recruits' strength was calculated based on the age groups from three to seven months; while the adult density was calculated considering the age groups between eight and 12 months. The maximum abundance of the recruits' strength was observed during the summer, while the maximum adults' density was observed during the end of summer and the beginning of autumn.

To validate the presence of all age groups within each index, Solana-Sansores et al. (1989) did not consider the effect of $F$ on the age groups nor the biological characteristics of the life cycle of the shrimp of the Penaeidae family. For this reason, the recruits' strength index presented a classification error because it included age groups of three, five, six and seven months. The three months age group resulted partially recruited to fishery and was underfished in this study. The five and seven months age groups are not considered as recruits according to various authors (Chávez 1974, Chávez 1979, Chávez \& Arreguín-Sánchez 1982, Penn \& Captuti 1984, Gracia et al. 1997, Reyna-Cabrera \& Ramos-Cruz 1998, Instituto Nacional de la Pesca 2004, Ramos-Cruz et al. 2006) and were underfished in this study.

According to Ricker (1975), recruitment is a process whereby organisms become potentially vulnerable to fishing as result of growth, change of behavior or movement into fishing areas. Gracia et al. (1997) considered two types of recruitment in the natural populations of shrimp: marine and lagoon. In this article, the marine recruitment is analyzed, and based on the results of fishery mortality rate. It seems that the massive marine recruitment of $F$. californiensis was shaped by a group of organisms that was beginning to be exploited at an age of four months ( $F_{4}=0.18$ monthly). Studies based on an analysis of the lagoon recruitment in the two coastal lagoons from the Gulf of Tehuantepec (the Sistema Lagunar Huave, Oaxaca and Laguna del Mar Muerto, Oaxaca/Chiapas) (Chávez 1974, Chávez \& ArreguínSánchez 1982, López-Rasgado 2003, García-Jiménez 2004, Instituto Nacional de la Pesca 2004), suggest that the age of $F$. californiensis recruitment is at four months and that the abundance of brown shrimp within these lagoons decreases between June and October, while it increases in the marine environment due to the recruitment process. This is a biological validation confirming the presence of the four months group in the FR index.
Gracia et al. (1997) indicated that the complete life cycle of the Penaeidae shrimp family is approximately between 15 and 18 months. Sexual maturity is generally reached between six and eight months, but the entire population is sexually mature between 10 and 12 months. The age of sexual maturity for $F$. californiensis from the Mexican Pacífic has been reported at seven months of age (Chávez 1979, Chávez \& Arreguín-Sánchez 1982, Reyna-Cabrera \& Ramos-Cruz 1998, Intituto Nacional de la Pesca 2004, Ramos-Cruz et al. 2006). This is also a biological validation confirming the presence of the age groups between six and 11 months in the DR index.

One additional work has used the FR and DR indices obtained in this article. Sánchez-Meraz (2005) correlated these indices with the annual variation of sea surface temperature (SST) and the concentration of chlorophyll $a$ (Chl $a$ ) from 1989 to 1998 . SST data were provided by the Physical Oceanography Distributed Active Archive Center (PODAAC) and Chl $a$ data were processed and obtained from Ocean Color and Temperature Sensor (OCTS) and Sea-Viewing Wide Field-of-View Sensor (SeaWIFS) images. SST was correlated (multiple correlation) with both population indices between 1989 and 1998 and additionally, with Chl $a$, from November 1996 to May 1998. In the first interval, SST had a directly proportional correlation effect to the recruits and inversely proportional to the spawners. The maximum FR abundances were observed between 29.3 and $29.7^{\circ} \mathrm{C}$, and the maximum DR abundances were observed from 28.1 to $28.7^{\circ} \mathrm{C}$. In the second interval, one maximum FR and two maximums DRs were observed, the first was observed with the SST one degree warmer than that registered during the maximum DRs. Chl $a$ was lower during the maximum FR abundance $\left(0.13 \mathrm{mg} \mathrm{m}^{-3}\right)$ and greater during the maximum DRs abundance $\left(0.42-1.10 \mathrm{mg} \mathrm{m}^{-3}\right)$. In this interval, SST and Chl $a$ had an inversely proportional correlation effect.

Considering the results obtained by Sánchez-Meraz (2005) and those reported by the Instituto Nacional de la Pesca (2004), I propose that between October and January (when the maximum abundance of spawners and the higher percentage of egg-laying of mature females in phase IV occurred), larval survival was greater because food was available due to the high levels of chlorophyll $a$ detected in the Gulf of Tehuantepec. On the other hand, from July to August/September (when the maximum abundance of recruits and the lower percentage of egglaying of mature females in phase IV occurred), larval survival was lower because food availability diminished due to the low levels of chlorophyll $a$ observed in the Gulf of Tehuantepec. 
In the Gulf of Tehuantepec, the Instituto Nacional de la Pesca (2005) indicated that the shrimp commercial catch obtained in Salina Cruz, Oaxaca and Puerto Chiapas, Chiapas presented several issues: a) unreported catches due to illegal fishing and presence of the Mexican fishery fleet from the northern states, b) the spatial distribution of the fishing effort in the sea is not in correspondence with the spatial distribution of some shrimp species abundance, c) insufficient knowledge of the annual variation of the abundance, and d) the lack of control over lagoon exploitation from minor fishing fleets. These issues related to the shrimp commercial catch were taken into account. The unreported catches were compensated for VPA (reconstruction of age-cohorts). This method only considered the commercial catch on the high sea. The shrimp lagoon catch was not taken into consideration because in this area of the Mexican Pacific this type of catch is scarce or is not registered.

In spite of the inconveniences associated with the use of the commercial catch data of brown shrimp, the analysis of this database is important for warning and correcting the use and management of the fisheries (Chávez \& Arreguín-Sánchez 1982). The proposed method for estimating abundance indices should be used in order to study the stock-recruitment relationships, the influence of environmental factors on these indices and the establishment of closures in shrimp populations both at national and international levels.

\section{Acknowledgments}

I would like to thank the CRIP of Salina Cruz, Oaxaca, México, for providing the database used in this research, and the Universidad del Mar (UMAR) for economic resources, also to ICMyL (UNAM). Sincere thanks to Sebastián Ramos-Cruz (CRIP-CS), Ragi A GuerraMendoza, Blanca Sánchez Meraz, Maria Isabel Gallardo Berumen, Edgar Robles Zavala, Derek Joe Brockett, Dean Richard Zrucky, Benedicte Frances Gueck (all UMAR) and the anonymous reviewers for their valuable time and comments regarding this article.

\section{Literature cited}

Chávez EA. 1974. Estudio preliminar la época de entrada de postlarvas de camarón a las Lagunas Oriental y Occidental en el Sistema Lagunar Huave, Oaxaca. Informe Definitivo, 269 pp. Escuela Nacional de Ciencias Biológicas, Instituto Politécnico Nacional, México.

Chávez EA. 1979. Diagnosis de la Pesquería del Camarón del Golfo de Tehuantepec, Pacífico Sur de México. Anales del Instituto de Ciencias del Mar y Limnología, Universidad Nacional Autónoma de México 6(2): 15-44.
Chávez EA \& F Arreguín-Sánchez. 1982. Evaluación y diagnóstico de la pesquería de camarón del Golfo de Tehuantepec. Informe Definitivo, 60 pp. Centro de Investigación y Estudios Avanzados, Unidad Mérida, México, Instituto Politécnico Nacional, México.

Gallardo-Berumen MI. 2005. Análisis del sistema de vedas sobre la explotación del recurso camarón en el Golfo de Tehuantepec. Tesis de Licenciatura, Universidad del Mar, Puerto Ángel, Oaxaca, México, 48 pp.

García-Jiménez MA. 2004. Variación estacional del reclutamiento de camarón en la Pampona (Playa Bernal) en la Laguna Mar Muerto, Oaxaca-Chiapas, México. Tesis de Licenciatura, Universidad del Mar, Puerto Ángel, Oaxaca, México, 95 pp.

Gracia A. 1991. Spawning stock-recruitment relationship of white shrimp in the southwestern Gulf of Mexico. Transactions of the American Fisheries Society 120: 519527.

Gracia A, AR Vázquez-Bader, F Arreguín-Sánchez, LE Schultz-Ruiz \& JA Sánchez. 1997. Ecología de camarones peneidos. In: Flores D, P Sánchez-Gil, JC Seijo \& F Arreguín-Sánchez (eds). Análisis y diagnóstico de los recursos pesqueros críticos del Golfo de México. Universidad Autónoma de Campeche, Epomex, Serie Científica: 127-144.

Hair F, J Anderson, L Tatham \& C Black. 1999. Multivariate data analysis, 542 pp. Prentice Hall, New Jersey.

Hannah RW. 1999. A new method for indexing spawning stock and recruitment in ocean shrimp, Pandalus jordani, and preliminary evidence for a stock- recruitment relationship. Fishery Bulletin 97: 482-494.

Instituto Nacional de la Pesca. 2004. Inicio de las temporadas de veda 2004 para la pesquería de camarón del Océano Pacifico Mexicano, 22 pp. Secretaría de Medio Ambiente, Recursos Naturales y Pesca, México.

Instituto Nacional de la Pesca. 2005. Plan de manejo para la pesquería en el litoral del Océano Pacífico Mexicano. Informe Definitivo, 76 pp. Secretaría de Medio Ambiente, Recursos Naturales y Pesca, México.

Lo NCH. 1978. California ocean shrimp mesh experiment. California Department of Fish and Game Fisheries 64(4): 280-301.

López-Rasgado F. 2003. Evaluación de la eficiencia de la red Renfro en el muestreo de camarón mediante experimentos de remoción en encierros en la Laguna Mar Muerto, Oaxaca-Chiapas, México. Tesis de Licenciatura, Universidad del Mar, Puerto Ángel, Oaxaca, México, 64 pp.

Penn JW \& N Captuti. 1986. Spawning stock-recruitment relationships and environmental influences on the tiger prawn Penaeus esculentus fishery in Exmouth Gulf, 
Western Australia. Australian Journal of Marine and Freshwater Research 37: 491-505.

Pielou E. 1984. The interpretation of ecological data, 263 pp. John Wiley \& Sons, New York.

Pope J. 1972. An investigation of the accuracy of virtual population analysis using cohort analysis. International Commercial Northwest Atlanta Fish Research Bulletin 9: 65-74.

Quinn II TJ \& RB Deriso. 1999. Quantitative Fish Dynamics, 542 pp. Oxford University Press, New York.

Ramos-Cruz S, B Sánchez-Meraz, F Carrasco-Ayuso \& $\mathbf{P}$ Cervantes-Hernández. 2006. Estimación de la tasa de mortalidad natural de Farfantepenaeus californiensis (Holmes 1900) y Litopenaeus vannamei (Boone 1931) en la zona costera del Golfo de Tehuantepec, México. Revista de Biología Marina y Oceanografía 41(2): 221-229.

Reyna-Cabrera IE \& S Ramos-Cruz. 1998. La pesquería de camarón de alta mar. In: Tapia-García M (ed). El Golfo de Tehuantepec: el ecosistema y sus recursos, pp.163-178. Universidad Autónoma Metropolitana-Iztapalapa, México.

Ricker WE. 1975. Computation and interpretation of biological statistics of fish population. Bulletin of the Fisheries Research Board of Canada 191: 1-382.

Sánchez-Meraz B. 2005. Respuestas del reclutamiento del camarón café Farfantepenaeus californiensis (Holmes 1900) a la variación interanual de la temperatura superficial del mar en el Golfo de Tehuantepec, Oaxaca. Tesis de Maestría, Universidad del Mar, Puerto Ángel, Oaxaca, México, 70 pp.
Sandoval-Quintero M E \& A Gracia. 1998. Stages of gonadal development in the spotted pink srhimp Penaeus brasiliensis. Journal of Crustacean Biology 18(4): 610-685.

Sepúlveda MA \& GLA Soto. 1991. Relación de la precipitación pluvial y la temperatura atmosférica sobre la producción camaronera del Golfo de Tehuantepec. Tomo II, pp. 665-667. VII Congreso Nacional de Oceanografía, Mazatlán, Sinaloa, México.

Sierra RP. 1993. Abundancia estacional de postlarvas de $P$. vannamei en la bocabarra de Tonalá, Chiapas, México. Informe Definitivo, 3 pp. Centro Regional de Investigación Pesquera de Salina Cruz, Oaxaca. Instituto Nacional de la Pesca, México.

Solana-Sansores R, F Arregín-Sánchez, R Castro \& M. Medellín. 1989. Exploración de técnicas multivariadas para uso en el estudio de la dinámica poblacional de especies sujetas a explotación pesquera: el caso del camarón café (Penaeus aztecus Ives 1891) del noroeste del Golfo de México. Boletin del Instituto Oceanografico de Venezuela 28(2): 245-252.

Sparre P \& SC Venema. 1995. Introduction to tropical fish stock assessment. FAO Fisheries Technical Paper 306: 1376.

Uriel E. 1995. Análisis de datos, series temporales y análisis multivariante, 433 pp. Universidad de Valencia, Madrid.

Watson RA, CT Turnbull \& J Derbyshire. 1996. Identifying tropical penaeid recruitment patterns. Marine and Freshwater Research 47: 77-85.

Ye Y. 2000. Is recruitment related to spawning stock in penaeid shrimp fisheries? Journal of Marine Science 57: 1103-1109.

Recibido el 24 de abril de 2007 y aceptado el 28 de enero de 2008 